\title{
Managing stress during the COVID-19 pandemic: The application of deep breathing relaxation technique and diary feedback among students
}

\author{
Yunita Zahra $^{1 *}$, Ika Sari Dewi ${ }^{1}$, Amalia Meutia ${ }^{1}$, Dina Nazriani ${ }^{1}$, Suri Mutia Siregar ${ }^{1}$, Omar \\ K. Burhan ${ }^{2}$ \\ ${ }^{1}$ Department of General and Experimental Psychology, Faculty of Psychology, Universitas Sumatera \\ Utara, Medan, Indonesia \\ ${ }^{2}$ Departement of Social Psychology, Faculty of Psychology, Universitas Sumatera Utara, Medan, \\ Indonesia
}

*Email: yunitazahra@usu.ac.id

\begin{abstract}
Having to stay at home and disconnected from their social world during the Covid-19 lockdown is stressful for many people, including students. The current paper reports the application of a deep breathing relaxation technique among students from the Faculty of Psychology Universitas Sumatera Utara, to regulate their stress levels at home. Twenty-five students participated in this intervention program. We trained them in a deep breathing relaxation technique and asked them to practice the technique twice a day, in the morning and the evening. We followed their progress for five consecutive days, in which participants filled a stress diary twice a day, in the morning and the evening. Based on the diary, a feedback by a psychologist was sent to each individual participant the next day. We assessed the effectiveness of the intervention program by comparing the students' perceived stress at the preintervention phase compared to their stress level at the post-intervention phase. The results showed a significant and meaningful impact of the intervention program, in which students reported lower perceived stress at the postintervention compared to the pre-intervention phase.
\end{abstract}

Keyword: stress, deep breathing relaxation, COVID-19 pandemic

\begin{abstract}
Abstrak
Harus tinggal di rumah dan terputus dari dunia sosial selama masa lockdown Covid-19 membuat banyak orang mengalami stres, termasuk mahasiswa. Manuskrip ini melaporkan penerapan teknik relaksasi pernapasan mendalam (deep breathing relaxation technique) pada mahasisa Fakultas Psikologi Universitas Sumatera Utara, untuk mengatur tingkat stres mereka di rumah. Dua puluh lima siswa berpartisipasi dalam program intervensi ini. Kami melatih mereka teknik relaksasi pernapasan mendalam dan meminta mereka mempraktikkan teknik tersebut dua kali sehari, pagi dan sore hari. Kami mengikuti perkembangan mereka selama lima hari berturut-turut, berdasarkan isian diari stres yang diisi oleh setiap individu partisipan. Diari ini diisi dua kali sehari, di pagi dan malam hari. Berdasarkan isian diari, umpan balik diberikan oleh seorang psikolog kepada setiap individu partisipan. Kami menilai efektivitas program intervensi dengan membandingkan stres yang dirasakan siswa pada waktu-1 (pra-intervensi) dibandingkan dengan waktu-2 (pasca-intervensi). Hasil menunjukkan dampak yang signifikan dan bermakna dari program intervensi ini, para mahasiswa yang terlibat melaporkan tingkat stres yang lebih rendah pada fase pasca intervensi dibanding fase pra-intervensi.
\end{abstract}

Kata Kunci: stres, relaksasi pernapasan mendalam, pandemi COVID-19

\section{PENDAHULUAN}

Stres dapat dialami oleh siapa saja, mulai dari anak-anak, remaja, dewasa bahkan sampai lanjut usia. Stres terjadi dalam berbagai peristiwa yang terjadi di masa kehidupan manusia. Dalam ilmu perilaku, stres merupakan suatu proses penilaian keadaan atau peristiwa dalam hidup sebagai sesuatu yang mengancam kesejahteraan hidup individu, yang tidak terduga dan di luar kontrol sang individu (Koolhaas et al., 2011). Stres dicirikan dengan kecemasan, depresi, ketidaknyamanan, ketegangan 
Yunita Zahra et.al. The application of deep breathing relaxation technique among students

emosional, dan sulit dalam melakukan penyesuaian diri (Fink, 2017). Mahasiswa termasuk golongan remaja akhir yang tidak luput dari stres (Shenoy, 2000). Berbagai tuntutan yang dialami mahasiswa dapat menjadi sumber stres yang kuat. Jaga Jarak Sosial diterapkan dalam usaha memutus mata rantai penyebaran virus COVID-19. Namun di sisi lain, menjaga jarak secara berkelanjutan dan dalam waktu yang tidak pasti bisa saja menimbulkan tekanan psikologis pada individu, tidak terkecuali mahasiswa. Stres berat di tengah pandemi bukanlah masalah yang bisa dibiarkan terjadi secara terus-menerus. Stres dapat mempengaruhi kesehatan fisik maupun psikologis. Hal ini tentunya akan mengganggu produktivitas individu tersebut. Lebih parahnya bila dibiarkan bisa mengarah pada kasus yang lebih ekstrim seperti percobaan bunuh diri maupun tindakan ekstrim lainnya.

Mempertimbangkan kesehatan psikologis para mahasiswa ini, maka dianggap perlu dilakukan intervensi agar mahasiswa mampu melakukan adaptasi terhadap stres. Salah satu mekanisme menghadapi stres adalah dengan relaksasi pernapasan mendalam (deep breathing relaxation technique). Penelitian telah menunjukkan potensi efektivitas teknik ini dalam mendorong perbaikan suasana hati dan stres secara efektif (Perciavalle et al., 2017). Dengan relaksasi pernapasan, diharapkan dapat memulihkan kondisi psikologis mahasiswa dan membangkitkan antusiasme siswa terhadap proses pembelajaran daring selama masa pandemi COVID-19.

\section{METODE PELAKSANAAN}

\subsection{Partisipan}

Partisipan di dalam kegiatan intervensi ini adalah 25 orang mahasiswa-mahasiswi Fakultas Psikologi Universitas Sumatera Utara $\left(M_{\text {usia }}=19.92, S D_{\text {usia }}=1.26\right.$, laki-laki $=3$, perempuan $\left.=22\right)$. Mereka berpartisipasi atas iklan kegiatan yang diumumkan via grup Facebook Fakultas Psikologi Universitas Sumatera Utara. Tidak ada paksaan untuk berpartisipasi, mereka berpartisipasi secara sukarela dan dapat meninggalkan kegiatan kapanpun mereka inginkan, sesuai dengan kode etik partisipasi kegiatan dan penelitian ilmu psikologi. Dari 25 orang yang mendaftar registrasi, 2 tidak berpartisipasi dalam fase pra-intervensi dan 3 tidak berpartisipasi dalam fase pasca-intervensi. Dengan demikian, total partisipan yang dapat diikutkan dalam mengevaluasi kegiatan ini adalah sebanyak 22 orang.

\subsection{Prosedur}

Kegiatan diawali dengan pembentukan tim kerja, studi literatur, pembuatan video dan persiapan kegiatan yang akan dilaksanakan. Setelah kami mempersiapkan segala hal yang berkenaan dengan kegiatan ini, para peserta melakukan registrasi melalui google form. Kami meminta peserta untuk mengisi lembar persetujuan sebagai peserta. Lembar persetujuan tersebut berisi komitmen dan hak-hak para peserta selama menjalani kegiatan intervensi ini. Proses penerapan metode relaksasi ini dilakukan secara mandiri oleh peserta dan monitoring dilakukan melalui whatsapp grup peserta, sehingga memang dibutuhkan kedisiplinan, komitmen dan kejujuran dari para peserta.

Di hari pertama kegiatan, (sehari setelah menandatangani lembar persetujuan partisipasi), para peserta menjawab kuesioner yang mengukur tingkat stres dan suasana hati mereka. Pengukuran ini dimaksudkan sebagai pengukuran tingkat stres pra-intervensi yang nantinya digunakan untuk mengevaluasi keberhasilan kegiatan ini. Sehari setelah dilaksanakan pengukuran stres pra-intervensi, kami menerapkan pengukuran kondisi stres harian para peserta. Data harian ini diambil sebanyak dua kali dalam sehari (siang dan malam hari) selama lima hari berturut-turut. Para peserta diinformasikan bahwa formulir ini merupakan diari tingkat stres mereka. Berdasarkan isian diari ini, mereka menerima umpan-balik dan saran-saran pengelolaan stres. Umpan balik per hari mereka terima via surel di pagi hari, di hari selanjutnya. Selain berisi pertanyaan tentang tingkat stres dan suasana hati, terdapat video relaksasi di awal formulir tersebut. Video relaksasi ini merupakan video yang kami buat sendiri. Peserta kami minta untuk mempraktikkan relaksasi sebagaimana ditunjukkan video tersebut. 

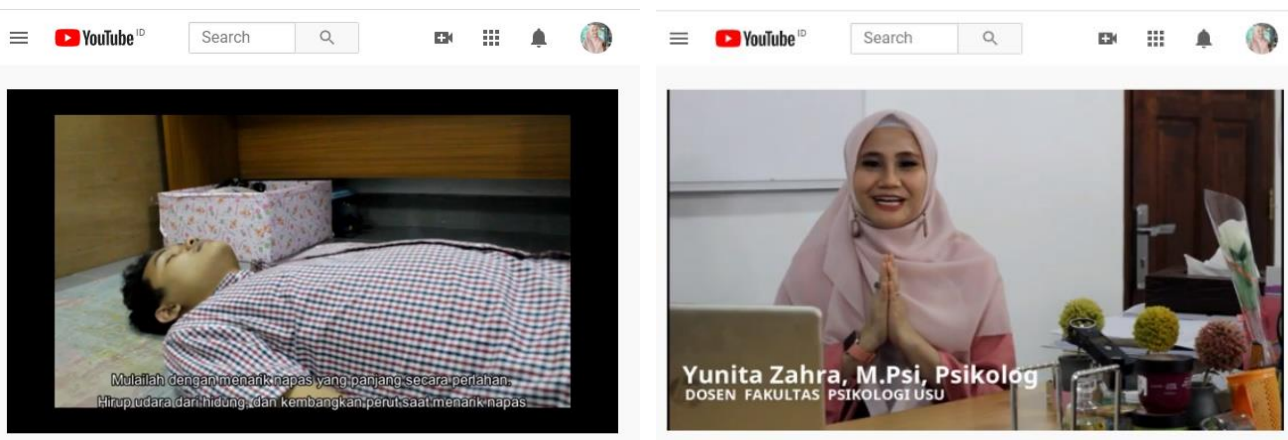

Gambar 1: Video Relaksasi yang tim buat

Di hari ketujuh, peserta kembali kami minta untuk menjawab kuesioner yang mengukur tingkat stres selama satu minggu belakangan dan evaluasi mereka terhadap kegiatan ini. Data ini dimaksudkan sebagai data pengukuran tingkat stres pasca-intervensi untuk mengevaluasi efektivitas kegiatan ini.

Setelah proses selesai, penulis mengucapkan terimakasih dan menanyakan bagaimana manfaat yang mereka rasakan dari program ini. Secara umum para peserta merasakan manfaat atas kegiatan ini dan berharap kegiatan serupa terus dilanjutkan. Sebelum menutup kegiatan program penerapan ini, sesuai dengan janji kami diawal, kami memberikan reward kepada 5 peserta secara random berupa uang senilai Rp. 75.000 per orang yang beruntung.

\subsection{Alat ukur}

Untuk mengukur tingkat stres pada fase pra-intervensi dan pasca-intervensi, kami mengadaptasi perceived stress scale (Cohen, Kamarck, \& Mermelstein, 1983). Alat ukur ini terdiri atas 10 butir ukur. Contoh butir ukur, misalnya: (1) "Sebulan terakhir, seberapa sering anda merasa kesal karena kejadian yang terjadi di luar dugaan Anda?", (2) "Sebulan belakangan, seberapa sering anda merasa berbagai hal berjalan sesuai dengan harapan anda?". Adapun format jawaban adalah skala likert 6 titik, dengan 0 = tidak pernah, 1 = hampir tidak pernah, 2 = kadang-kadang, 3 = cukup sering, 5 = sangat sering. Analisis reliabilitas Cronbach's alpha menunjukkan bahwa alat ukur ini reliabel, baik pada fase praintervensi $(\alpha=.83)$ maupun pada fase pasca-intervensi $(\alpha=.89)$.

\section{HASIL DAN PEMBAHASAN}

\subsection{Efektivitas intervensi}

Intervensi ini dikatakan berhasil apabila terjadi penurunan persepsi stres pada saat saat pasca-intervensi, dibanding saat fase pra-intervensi. Paired-sample t-test menunjukkan bahwa para partisipan melaporkan tingkat stres yang lebih rendah pada fase pasca intervensi $(M=2.26, S D=0.34)$ dibanding pada fase pra-intervensi $(M=2.41, S D=0.28), t(20)=-2.32 p=.031, d=0.50$. Nilai $p<.05$ berarti bahwa perubahan tingkat stress pada fase pasca-intervensi bukan terjadi karena kebetulan, akan tetapi dapat diyakini sebagai dampak nyata penerapan intervensi.

Selain itu, nilai effect size $d=.50$, berarti bahwa intervensi ini telah memberikan dampak pada kategori menengah (Nolan \& Heinzen, 2012), suatu kategori yang menunjukkan bahwa perubahan sebesar 0.15 pada fase pasca-intervensi sebagai sesuatu yang bermakna. Namun, ini juga berarti bahwa meskipun program intervensi ini telah berhasil menurunkan tingkat persepsi stres para partisipan, ada faktorfaktor lain yang juga ikut menentukan stres para partisipan, yang tidak dipertimbangkan di dalam kegiatan ini. Representasi grafik dari hasil kegiatan ini dapat dilihat di Grafik 1. 
Yunita Zahra et.al. The application of deep breathing relaxation technique among students

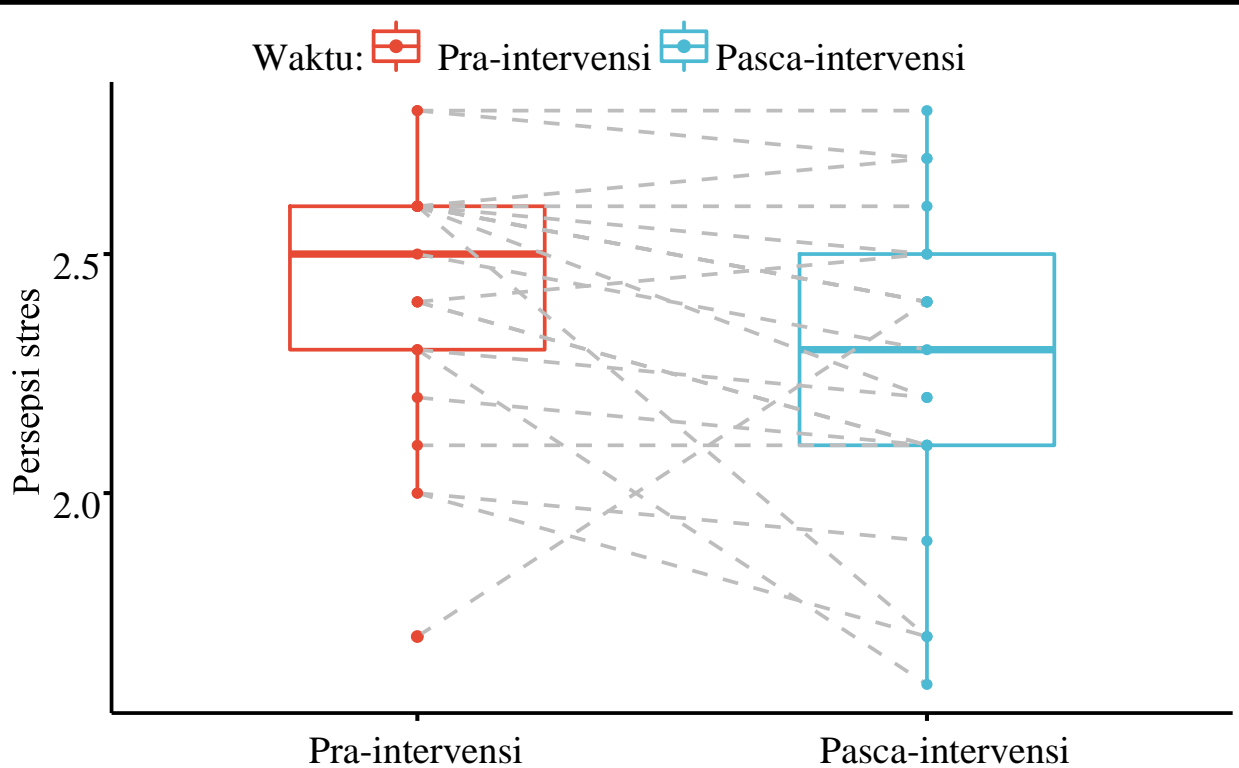

Grafik 1: Penurunan persepsi stres di fase pasca-intervensi dibanding fase pra-intervensi

\subsection{Dinamika stres harian peserta}

Untuk melihat perubahan stres harian peserta, kami melakukan analisis repeated measure Anova dengan hari (hari 1, hari 2, hari 3, hari 4, dan hari 5) dan waktu (siang dan malam) kami perlakukan sebagai within subject factors. Hasil menunjukkan bahwa tidak ada perubahan stress yang signifikan per harinya pada para partisipan, $F(4,52)=0.76, p=.557$. Akan tetapi, ada efek signifikan waktu (siang vs. malam) terhadap tingkat stres para peserta, $F(1,13)=4.95, p=.044$. Sebagaimana ditunjukkan

Grafik 2, para partisipan tampak lebih stress di siang hari dibanding pada pagi hari. Akan tetapi, pairwise comparison test dengan metode koreksi Bonferroni menunjukkan bahwa efek waktu (siang vs. malam) ini tidak bermakna, $t(218.19)=-0.63, p=.530$. Dengan demikian, meskipun secara keseluruhan, stres pada pasca-intervensi lebih rendah daripada stres pada pra-intervensi, pola penurunan stres tidak dapat dilihat dari analisis harian. Dengan demikian, dampak program intervensi ini lebih bersifat global, tetapi tidak pada kegiatan harian para partisipan. Oleh karena itu, intervensi lanjutan perlu menemukan sebuah cara yang tidak hanya menurunkan tingkat stres yang bersifat global, akan tetapi juga pada level harian.

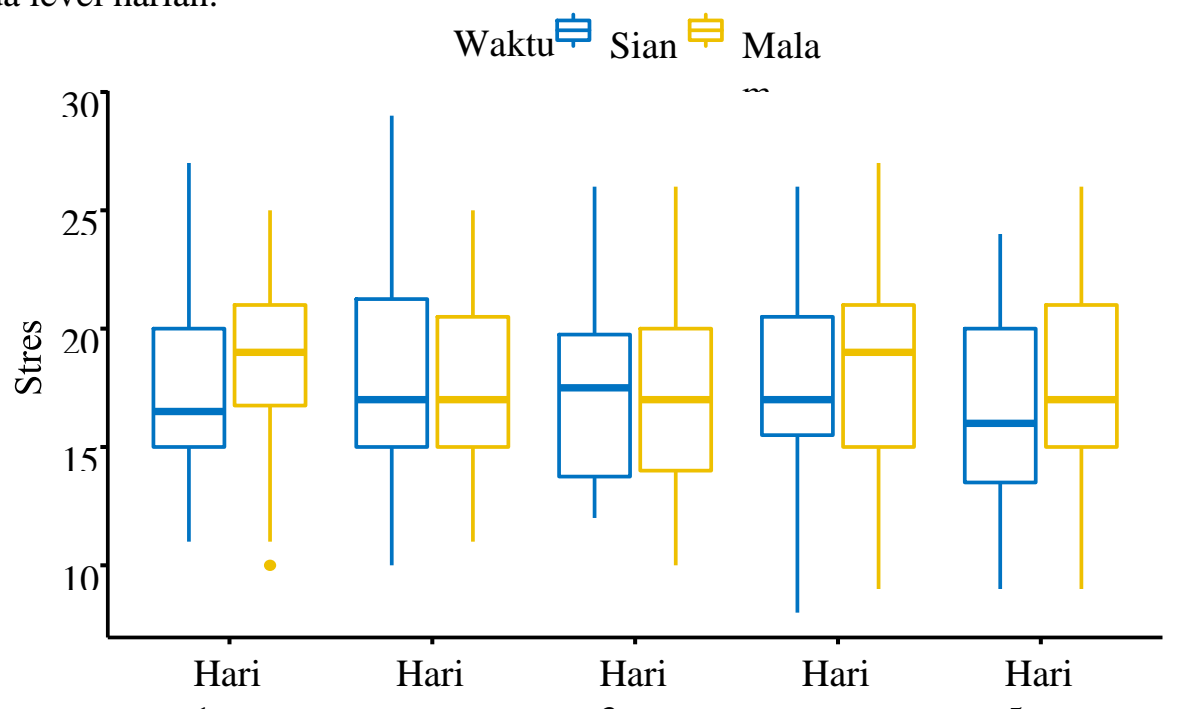

Grafik 2: Dinamika stres berdasarkan hari dan waktu 
Yunita Zahra et.al. The application of deep breathing relaxation technique among students

\subsection{Testimoni partisipan intervensi}

Secara umum para partisipan merasa program intervensi ini sebagai bermanfaat. Sebagian mengungkapkan sarannya agar program ini dilanjutkan, khususnya pada target mahasiswa yang mengalami stress, khususnya di masa pandemi COVID-19. Beberapa penggalan komentar yang diberikan peserta dapat dilihat pada Gambar 2 dan 3.

Pesan/kesan/saran untuk panitia

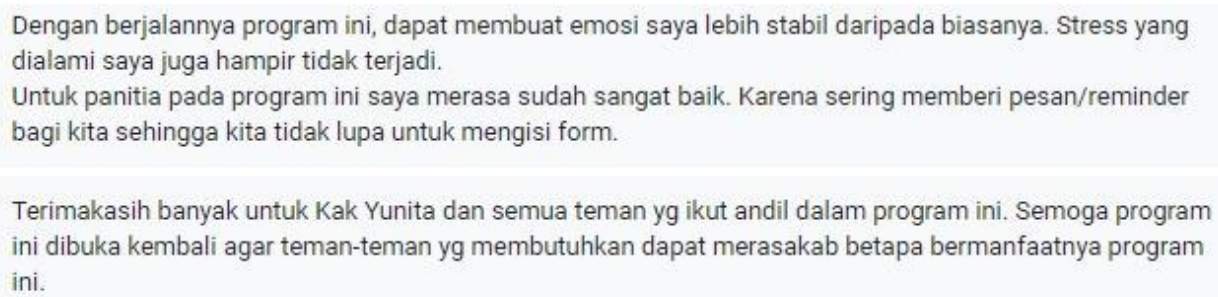

Gambar 2: Kesan dan pesan dari partisipan 1

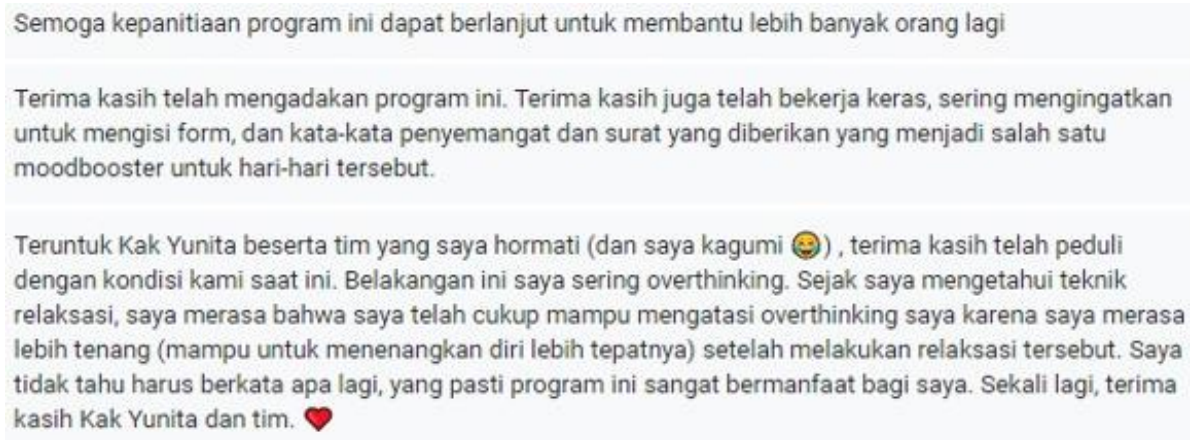

Gambar 3: Kesan dan pesan dari partisipan 2

\section{KESIMPULAN}

Kegiatan pengelolaan stres ini dikatakan berhasil karena terjadi penurunan persepsi stres antara saat fase pra-intervensi dan pasca-intervensi. Teknik relaksasi mendalam yang dibarengi dengan umpan balik terhadap diari stres telah mampu menurunkan persepsi stres para partisipan. Dengan relaksasi Penurunan tingkat stres yang signifikan ini mengindikasikan keberhasilan kegiatan dalam mengurangi stres pada para mahasiswa.

\section{UCAPAN TERIMAKASIH}

Penulis mengucapkan terimakasih kepada Fakultas Psikologi USU yang mendukung kegiatan pengabdian mandiri kami. Terima kasih secara khusus kepada tim mahasiswa-mahasiswi yang telah terlibat dan membantu jalannya kegiatan ini yaitu: Natalia Valencia, Raka Aditya, Blandina Elni Silalahi dan Christoffel Togos Imanuel Sirait.

\section{DAFTAR PUSTAKA}


Yunita Zahra et.al. The application of deep breathing relaxation technique among students

Cohen, S., Kamarck, T., \& Mermelstein, R. (1983). Perceived Sress Scale. Journal of Health and Social Behavior, (24), 386-396.

Fink, G. (2017). Stress: Concepts, Definition and History 败. In Reference Module in Neuroscience and Biobehavioral Psychology (pp. 1-9). Elsevier. https://doi.org/10.1016/B978-0-12-8093245.02208-2

Koolhaas, J. M., Bartolomucci, A., Buwalda, B., de Boer, S. F., Flügge, G., Korte, S. M., .. Fuchs, E. (2011). Stress revisited: A critical evaluation of the stress concept. Neuroscience and Biobehavioral Reviews, 35(5), 1291-1301. https://doi.org/10.1016/j.neubiorev.2011.02.003

Nolan, S. A., \& Heinzen, T. E. (2012). Statistics for the behavioral sciences. 2( עלון הנוטע ed., Vol. 66). New York: Worth Publisher.

Perciavalle, V., Blandini, M., Fecarotta, P., Buscemi, A., Di Corrado, D., Bertolo, L., ... Coco, M. (2017). The role of deep breathing on stress. Neurological Sciences, 38(3), 451-458. https://doi.org/10.1007/s10072-016-2790-8

Shenoy, U. A. (2000). College-stress and symptom-expression in international Students : A comparative study. Virginia Polytechnic Institute and State University, Virginia. 